\title{
REFERENCES.
}

Bennett. -Trans. Ophthal. Soc. U.K., Vol. XXI, p. 43, 1901.

Collins.-(1) Ibid., Vol. XL, p. 406; (2) Researches Anat. and Path. of Eye, London, p. 33, 1896; (3) Trans. Ophthal Soc. U.K., Vol. XV, p. 104 1895 ; (4) Ibid., Vol. XXXVI, p. 403, 1916.

Dub.-Archiv f..Ophthal., Vol. XXXVII, pp. 4, 26.

Duke-E1der.-Recent Advances in Ophthalmology. London, 2nd Edit., 1929.

Edmunds.-Proc. Roy. Soc. Med., Vol. IX, Pt. 3, p. 53, 1916.

Friedenwald.-Pathology of the Eye. London, 1930.

Fuchs.-(1) Text-book of Ophthalmology. Philadelphia, 8th Edit. (Trans. Duane) ;

(2) Ueber traum. Linsentrubungen. Wiener klin. Wochenschr. 1888.

von Graefe.-Arch. f. Ophthal., Vol. III, p. 372, 1857.

Gunn.-Trans. Ophthal. Soc. U.K., Vol. XV, p. 121, 1895.

Horner.-Zur Lehre v. Schichtstaar. Inaug. Dissert., Zürich, 1865.

Hudson.-Roy. Lond. Ophthal. Hosp. Rep., Vol. XVIII, p. 112.

Jeremy.-Brit. Jl. of Ophthal., p. 315, 1919.

Knapp.-Arch. of Ophthal., Vol. XXXV, p. 141.

Leber.-(1) Berichte d. ophthal. Gesellschaft zu Heidelberg, p. 33, 1878 ; (2) Arch. f. Ophthal., Vol. XXVI, pp. 1, 283.

Mann.-Development of Human Eye. Cambridge, 1928.

Mayou.-Trans. Ophthal. Soc. U.K., Vol. XXV, p. 88, 1905.

Merz-Weigandt.-Cent. $f$. prakt. Augenheilk., Vol. XXIV, p. 353, 1900.

zur Nedden.-Zeitschr. f. Augenheilk., Vol. II, p. 389, 1904.

Nettleship.-Bowman Lecture, 1909. Trans. Ophthal. Soc. U.K., Vol. XXIX.

Parsons. - (1) Pathology of the Eye. London, 1904; (2) Diseases of the Eye. London, 6th Edit., 1931.

Peters.-Arch. f. Ophthal., Vol. XXXIX, p. 221, 1893.

Schiller.-Beitr. z. klin. Chir., Vol. XXIV, p. 586, 1899.

Schirmer.-Arch.f. Ophthal., Vcl. XXXV, pp. 3, 147.

Schlösser.-Experim. Studie u. Traum. Kat. München, 1887.

Stein.-Beitr. z. A ugenheilk., Vol. VII, Helt. 63, 42, 1904.

Vossius.-Arch. of Ophthal., Vol. XXXV, p. 566, 1906.

Walter.-Ueber traumatischen Schichtstaar. Inaug. Dissert., Rostock, 1917.

Weiss.-Zeitschr. f. Augenheilk., Vol. VIII, p. 37, 1902.

Westphal.--Berl. klin. Wochenschrift, Vol. XXXVIII, pp 33, 849, 1901.

Whiting.-Trans. Ophthal. Soc. U.K., Vol. XXXVI, p. 167, 1916.

\section{GLIOMA OF THE OPTIC NERVE}

BY

\section{BERNARD GLUCK}

CARDIFF

Gliomata of the optic nerve are rare, but not excessively so. Surveying the literature up to that date, Hudson ${ }^{1}$ in 1912 was able to collect 118 cases which, after reviewing the published reports and where necessary modifying the original diagnosis, he was able to classify as gliomata or probable gliomata. In 1930, Mathewson $^{2}$ was able to trace 52 additional cases, so that up to the present less than 200 cases have probably been reported. But in the lifetime of the individual surgeon it is unlikely that more than one or two cases will come under his care; thus, according to 
Musial $^{3}$, Treacher Collins saw during a period of 15 years in 400,000 patients only 2 cases of primary neoplasm of the optic nerve; Sattler 10 cases in 400,000 patients.

The case here reported has additional interest in two respects :

1. As far as I can trace, it is the first recorded in which radium was used as the primary and only treatment, i.e., without previous removal of the tumour or as much of it as was accessible for removal.

2. The diagnostic problem presented by the case when it was seen early this year and before the previous history could be traced.

D.L., a female child, was admitted to Llwynypia Hospital, Rhondda, on December 26, 1931. The left eye was stated to have been removed 7 years ago after an injury to it by a snowball, and since then the child was said to have had "fits," and for three days before admission to have been unable to swallow.

On admission: the left eyelids, which were entirely devoid of lashes, were completely adherent to each other, the skin passing across the front of the orbit in an unbroken sheet. The orbital contents were tense, fluctuating, but not tender. There was some oedema of the skin but no signs of superficial or deep inflammation. There was loss of nearly all the hairs of the heft eyebrow and there appeared to be atrophy of the upper margin of the orbit and superciliary ridge, which could not be felt. The child was clearly mentally backward but quite happy, did not complain of headaches, and no fits were observed until a few days before death.

On January 1, 1932, Mr. Melbourne Thomas, Medical Superintendent, made an incision along the line of the adherent lid-margins. A thick fibrous membrane was exposed and deep to this a thin transparent layer. A needle was passed in and 10 c.c. of clear, deep yellow fluid, which clotted spontaneously, were withdrawn.

On January $5 \mathrm{I}$ was asked to see the child. The cyst had again filled and the whole orbital region was tense and fluctuating. At this stage our diagnosis was a cystic condition of the orbit, probably connected with the removal of the eye, but there were some features which were very puzzling, especially the character of the fluid and the absence of a conjunctival sac if the eye had been removed on account of an injury. Therefore, with a view to determining the limits of the cavity, 35 c.c. of fluid were again aspirated (of similar nature to that previously obtained) and about 2 c.c. of lipiodol injected through the same needle. After removal of the fluid, definite pulsation could be felt in the orbit. $\mathrm{X}$-ray photographs were then taken with the head in several positions. The plates 
showed lipiodol well above the roof of the orbit and also behind the apex, in addition to masses in the orbital cavity (Fig. 1).

It was only a few days later that it was possible to trace the notes of her previous treatment, and I am indebted to Mr. Leighton Davies, under whose care she had been, for permission to publish these.

In January, 1925, she was brought to the Cardiff Royal Infirmary on account of being. blind in the left eye. This was first noticed a

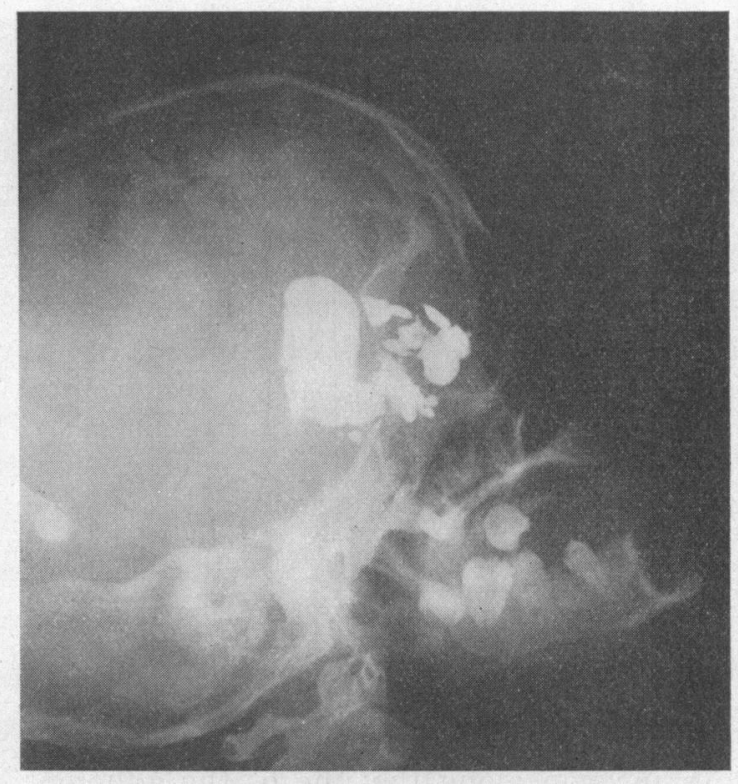

FIG. 1.

week previously, after being struck on the eye by a snowball. The left eye was blind, disc pale, veins at lower edge full, tortuous and ill-defined in parts. There was no proptosis.

In October of the same year she was brought up again. There was now marked proptosis of the left eye directly forwards; the eye could not be pushed back and there was a sensation of something solid behind the globe ; movements were fairly free in all directions. The fundus was as before. The protopsis increased during the next month and the child was admitted with the diagnosis of probable optic nerve tumour.

On November 27, after splitting of outer canthus and resection of external rectus muscle the orbit was explored and a firm mass felt at apex. Complete removal was considered impossible and a needle 
of $50 \mathrm{mg}$. of radium inserted into the orbit to lie against the tumour and left 48 hours. There was considerable reaction with increase of proptosis. From exposure of the cornea an ulcer developed which perforated, so that on the 16th December the eye was enucleated. A firm mass was felt at apex of orbit, extending on to floor and outer wall. Five needles of $50 \mathrm{mg}$. radium each were inserted into orbit and left for 48 hours. The reaction was moderate except for oedema of the lids, and she was discharged after a week.

On February 11, 1926, she was readmitted. There was swelling of the lids which were slightly cyanotic, the conjunctiva at centre of socket was sloughy, and a hard mass was felt about half way back in orbit. Two needles of $50 \mathrm{mg}$. radium each were inserted into this mass (some force was required) and left 48 hours. A good deal of reaction followed. She was seen several times in outpatients up to May, and again in January, 1927, when the lids were still oedematous and a green slough was seen in socket. This, as far as we can trace, was the last time she attended at the Cardiff Royal Infirmary.

With these notes available, the diagnosis now became fairly clear. There was no change in the child's condition until January 18 , when she began to complain of headache and vomited. She became increasingly drowsy and irritable and died on January 22.

Permission for a partial post-mortem only could be obtained and this was carried out by Dr. Roberts, of Llwynypia Hospital, to whom I am much indebted for this and other assistance with the case.

The brain with the dura mater of the floor of the skull, part of the frontal bone and the contents of the left orbit, were removed. The whole roof of the orbit was absent, the atropy of the bone extending up to the superciliary ridge. There was a large cystic growth in the lower part of the left frontal lobe, which extended down to fill the orbit, pushing the dura before it. The dura was not infiltrated by tumour nor was it adherent to the brain. Only towards the apex of the orbit was a small piece of tissue found which appeared to represent the original contents of the orbit. The cavity of the tumour contained lipiodol, none was present in the ventricles. The left lateral ventricle was very greatly enlarged, the right one less so. The tumour extended up to involve the greater part of the lenticular nucleus.

Sections were taken from several parts of the brain tumour and showed the characteristic structure of a glioma (Figs. (2) and (3). It was possible microscopically to identify the stump of the optic nerve in the extra-dural tissue found at the apex of the orbit: astrocyte cells were found within the dural sheath (Fig. 4), but on the whole the tissue here had more the character of neural granulation tissue than of true neoplasm. 


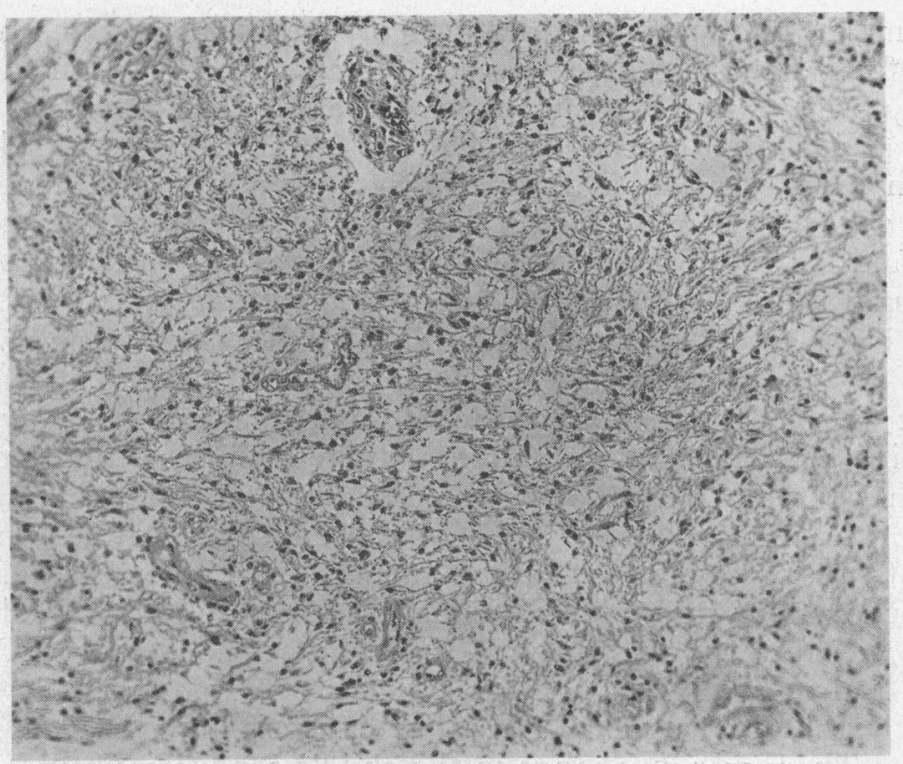

FIG. 2.

Haematoxylin-eosin. $\times 110$

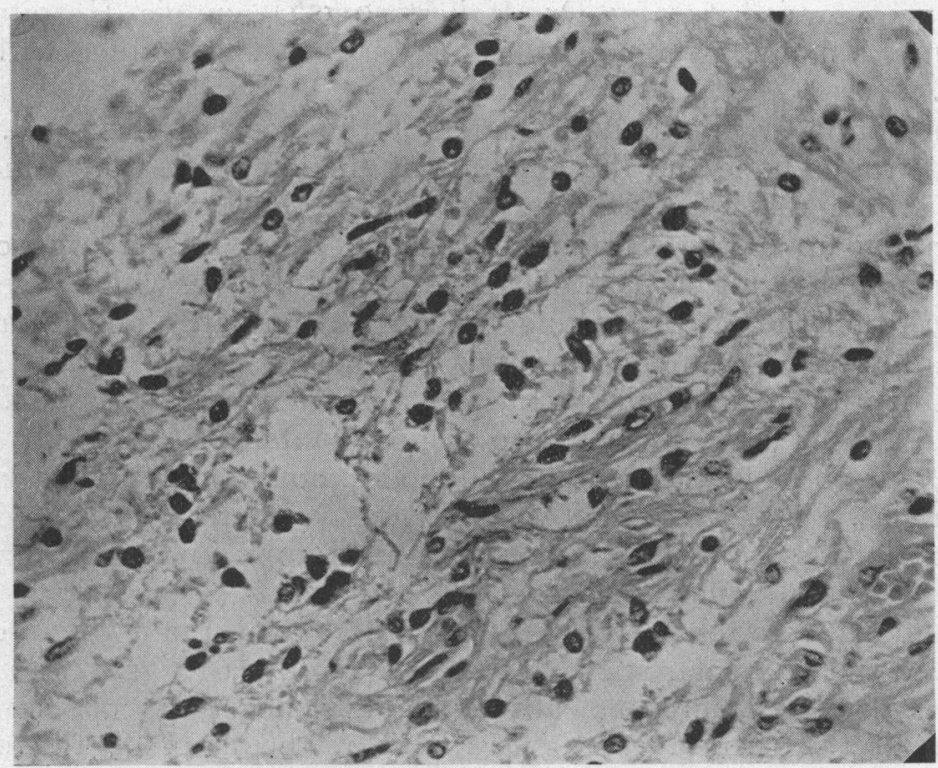

Fig. 3.

Haematoxylin-eosin. $\times 400$ 


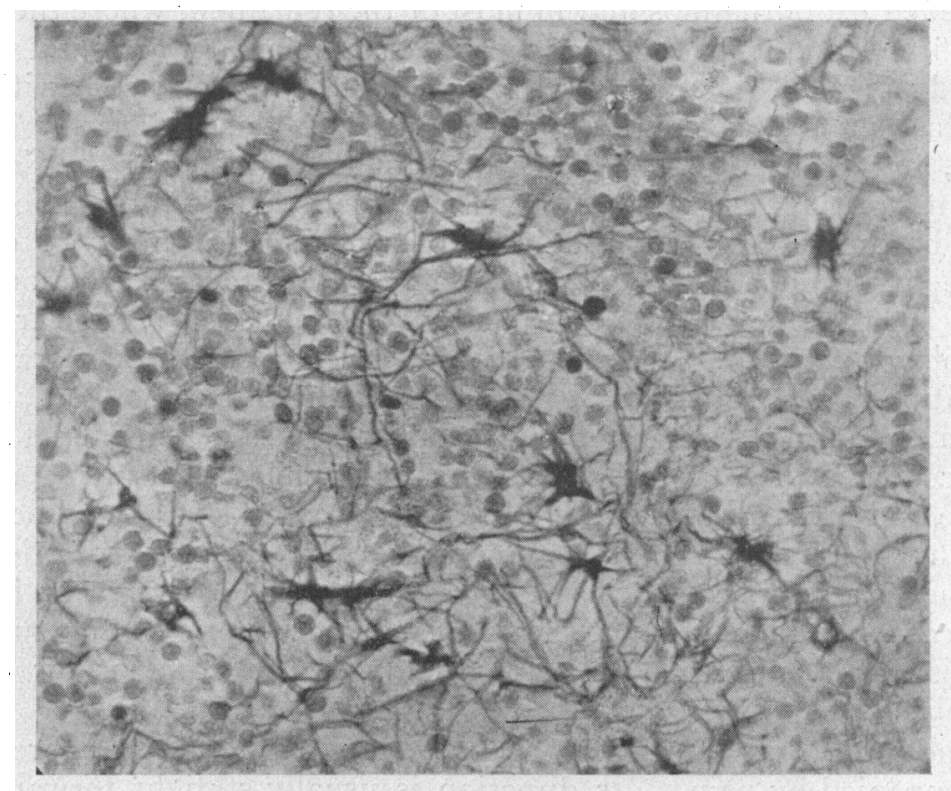

Fig. 4.

The clinical features of primary tumours of the optic nerve have been well summarised by Hudson ${ }^{1}$ in an exhaustive paper published in 1912 in which he collected all the previously reported cases. From a critical examination of the records he was able to classify the cases into three groups, of which gliomata formed by far the largest. Of 181 cases collected, 21 could not be classified with any degree of certainty. Of the remaining 160,118 could be regarded with a fair degree of certainty or probability as "gliomatosis;" 6 were grouped as "fibromatosis" of the sheath; 29 as " endothelial tumours" of the sheath, and 7 as possibly "endothelial tumours" of the sheath.

Except for the substitution of the terms "glioma," "fibroma," and "meningioma," the above classification has been adopted by nearly all subsequent writers. Mathewson, ${ }^{2}$ in a survey of the literature since 1912, found 61 additional cases, of which 52 were glioma, 9 meningioma, and 1 a fibroma. The great preponderance of gliomata is very definite. The subsequent remarks refer to the gliomata or "primary intraneural tumours."

Sex appears to play a small part; of 113 of Hudson's series where the sex was stated, 70 (62 per cent.) were females. The age of onset of symptoms is highly characteristic, the first symptoms being noted before 10 years in 62 per cent. and before 20 years in 88 per cent. of the cases of Hudson's series. In the majority of cases defect of vision 
preceded exophthalmos and in most of the remainder where the case was first brought up because of proptosis, the sight was found to be already aftected. As unilateral impairment or loss of vision without external signs is frequently not recognised by the patient for some time, and especially so in the case of children, it is clear that in the vast majority of cases defect of vision occurs before tumour formation becomes obvious through proptosis. In a number of cases there has been a history of antecedent injury to the skull or the eye. In the present case this history is definite, but it is clear that the blow by a snowball could have played no part beyond drawing attention to the blindness of the eye, as the disc was already pale when seen one week after the injury. Hudson considered that antecedent injury or disease was of some moment as a predisposing cause and gives a list ranging from injury to the skull to whooping cough; but if one recalls how constantly an injury is recollected whenever anything abnormal appears about a child's eyes or head, one can only conclude that the case is no more proved for such a predisposing cause than it is for glioma of the brain or for most neoplasms.

The proptosis is usually of slow progress and therefore not accompanied by pain. Its direction is usually straight forwards, a characteristic of growths within the muscle cone. When the tumour is large, however, some deviation from this direction is not unusual. Movement of the eyeball is commonly but little restricted or not at all so; this is mainly due to the fact that the growth does not transgress the limits of the nerve sheath and does not infiltrate the muscles and other tissues, and partly to the growth being usually in the posterior end of the nerve, the anterior end remaining sufficiently supple to allow the eyeball to turn.

As regards the ophthalmoscopic conditions found, in the great majority of cases the changes were those of post-neuritic atrophy. In the case here described, the disc still showed signs of papillitis although pallor was already definite when first seen. In some cases, however, primary optic atrophy has been noted. It seems that the appearance of the disc may depend largely on the position of the tumour: if near the eyeball, swelling of the disc with engorgement of the veins and later atrophy of the secondary type results from interference with the venous drainage; when the growth is far back primary optic atrophy would tend to result. Thus Martin and Cushing, ${ }^{4}$ in a series of 7 cases where the growth appeared to originate in the chiasma and the optic nerve near it, found definitely primary atrophy in 5 of them.

In view of the marked tendency of the growth to spread centripetally along the nerve, it is rather surprising that descent towards the eye and into the nerve-head has only been recorded rarely. Two cases are reported by Verhoeff. ${ }^{5}$ In the one case there was 
found ophthalmoscopically, 3 years after the eye was found to be blind and 2 years after the onset of proptosis, a cystic mass protruding from the site of the disc. Microscopical examination showed that the optic disc was replaced by an overgrowth of neuroglia, which also involved the adjacent retina for $1-3 \mathrm{~mm}$. The neuroglia at the summit of the disc had proliferated into the vitreous and this mass contained a cyst. In the other case gliomatous involvement of the disc was found microscopically. A third case is that of Martin and Cushing ${ }^{4}$ of a chiasmal glioma where a swelling of the disc, considered as papilloedema, was found post-mortem to be due to extension of the gliomatous process to the disc. Weigelin ${ }^{6}$ recently reported a case of glioma of the nerve in which a greyish yellow mass was seen on the disc. After exenteration this was found to be tumour tissue extending into the eyeball from the growth in the nerve. A fifth possible case is that of Sulzer and Rochon-Duvigneaud" where in a "neoplasm" of the optic nerve the disc was found to be replaced by a solid vascular growth. It does, however, appear from these that in cases of suspected glioma of the optic nerve particular attention should be paid to the character of any swelling of the disc.

Hypermetropia, due to pressure on the back of the globe, has been noted in several cases; in one, that of Collins and Marshall, ${ }^{8}$ it was seen to increase during the period of observation.

In a few cases the growth in the orbit has attained sufficient size to distend its walls. In two of Hudson's series there was erosion of the bones at the base of the skull from intra-cranial extension, as in the case here reported.

The tendency of the growth is to extend along the optic nerve to the chiasma and brain, confining its spread to nervous tissue only. In no case has it been found to penetrate the dura and involve the other tissues of the orbit. It is therefore not surprising that local recurrence has never been recorded, though removal has in many cases been admittedly incomplete and in many more was probably incomplete. Many authors lay stress on this point and the tumour is regarded as of low malignancy. Musial ${ }^{3}$ goes so far as to state that such tumours show "no characteristic of malignancy" because of the slow growth and absence of local recurrence, metastases, or involvement of lymph glands. A perusal of the published cases makes it quite impossible to accept this view of non-malignancy. In most of the cases which for any reason came to post-mortem, extensive intracranial involvement was found, and in others it was suspected at the time when the case was reported and the patient was still alive. Owing probably to the slow rate of growth of the intracranial extension, severe cerebral symptoms have often been long delayed and there can be no doubt that the number of cases where an optic nerve glioma ultimately killed the patient would have been 
found to be much larger if the cases could have been kept under observation for a sufficiently long time. The case here recorded illustrates this, as for five years the cerebral symptoms were apparently not sufficiently severe to lead the mother to bring the child back to the hospital. A few cases have been reported where good health was present for many years, even as many as 24 .

Within the last 15 years, largely as the result of the work of neuro-surgeons, gliomata of the brain have been divided into a large number of subdivisions according to the histological characters of the chief cells. Bailey and Cushing ${ }^{9}$ have divided them into 12 groups, Penfield ${ }^{10}$ into 8 . In view of the origin of the optic nerve, there is no reason why most of the types found in the brain should not also occur in neuroglial tumours starting in the optic nerve, and it would be desirable to investigate these growths with this in view. Recent methods of glial staining, on which the sub-classification of gliomata has been largely based, require special methods of fixation of the specimen, as described in Cushing's book. In the present case this was not possible and the tumour cannot with confidence be classified further than as a glioma. It is of considerable interest that Cushing and others have found that the subdivision of the gliomata by their histological characters has not only an academic interest, but that the different groups have fairly distinctive characteristics of growth and corresponding prognosis. Thus, in the case of gliomata of the brain, patients with multiple spongioblastomas have a probable survival period of a few months only, and at the other end of the scale, those with astrocytomas (the commonest glioma) may expect a survival of $2-20$ years. It is possible that it is a preponderance of the slower growing types of glioma which accounts for the relatively long survival after incomplete removal of optic nerve gliomata, and has led to these tumours being regarded as of low malignancy.

Most of the cases of glioma of the optic nerve have come primarily to the notice of the ophthalmic surgeon-on account of proptosis or loss of sight - and consequently most of the reported cases have been of intra-orbital, or mainly intra-orbital, tumours. Since the growth of intra-cranial surgery and especially the attention paid to lesions in the region of the pituitary fossa, it has of late years become increasingly evident that the intra-cranial portion of the nerve and the chiasma may also be involved, without or before any clinically recognisable tumefaction of the orbital part of the nerve. Martin and Cushing ${ }^{4}$ reported 7 cases of primary gliomata which appeared to originate either in the chiasma or the optic nerves adjacent. In 5 of these a correct localising diagnosis of suprasellar lesion had been made, but in only one was the probable character of the growth surmised before operation. Dandy ${ }^{11}$ has also drawn attention to the fact that many intra-orbital optic nerve 
tumours will be found to involve the intra-cranial structures, though the two cases he reports are both meningiomata and not gliomata.

As regards treatment, this has always consisted in removal of the tumour, frequently incomplete, with or without the globe. In the present case, owing to the position far back in the orbit, no attempt at removal was made but radium applied near and within the tumour on three occasions. Although the radium treatment did not succeed in arresting the growth, it is at least noteworthy that no tumour mass, except a small nodule no larger than the stump of an optic nerve, was found post-mortem in the orbit. Possibly the growth had already extended into and behind the optic canal, beyond the reach of radiation-the position of the tumour far back in the orbit suggests this.

Another point which stands out in this connection is the extreme slowness of the tissue ulceration resulting from radium. For at least a year after it was last used the lid margins were still intact, but the tissues were breaking down and ultimately the whole conjunctiva and the lid margins with their hair-follicles were destroyed, so that the final appearance was as if an exenteration of the orbit had been performed, and the epilatory effect even extended to the hairs of the eyebrow.

If, in removal of such a tumour, the globe is to be preserved the choice of access is between a Kroenlein operation or approach through either fornix; of the latter that through the outer fornix with temporary resection of the external rectus probably gives the best access. But preservation of the eyeball can only be of cosmetic value in these cases, and if a more serious view of the malignancy of these tumours is taken than formerly-and I think it must be when the frequency of intracranial extension is considered-then the retention of a sightless globe will be considered a small factor as compared with the better access after enucleation.

I wish to express my thanks to Mr. Melbourne Thomas for permission to publish the case, to Acting Professor Duguid, Department of Pathology, Welsh National School of Medicine, for granting me facilities for the microscopical examination of the specimen, and to Dr. Gough for his valuable assistance with this part of the work.

\section{REFERENCES}

1. Hudson.-Roy. Lond. Ophthal. Hosp. Reps., Vol. XVIII, p. 317, 1912.

2. Mathewson.-Amer. Jl. of Ophthal., Vol. XIII, p. 880, 1930.

3. Musial.-Zeitschr.f. A ugenheilk., V̈ol. LXXII, p. 189, 1930.

4. Martin and Cushing.-Arch. of Ophthal., Vol. LII, p. 209, 1923.

5. Verhoeff.-Arch. of Ophthal., Vol. I. , p. 120, 1922.

6. Weigelin.-Klin. Monatsbl. f. Augenheilk., Vol. LXXXVII, p. 527, 1931.

7. Sulzer and Rochon-Duvigneaud.-Ann. d'Ócul., Vol. CXLIX, p. 161, 1913.

8. Collins and Marshall.-Trans. Ophthal. Soc. U.K., Vol. XX, p. 156, 1899.

9. Bailey and Cushing.-Classification of the Tumours of the Glioma Group. 1926.

10. Penfield.-Brit. Med. Jl., Vol. I, p. 337, 1931.

11. Dandy.-Amer. Jl. of Ophthal., Vol. V, p. 169, 1922. 